\title{
Evaluation of endoscopic laser excision of polypropylene mesh/ sutures following anti-incontinence procedures
}

\author{
Davis NF, Smyth LG, Giri SK, Flood HD \\ Department of Urology, Mid-Western Regional Hospital, Dooradoyle, Limerick, \\ Ireland
}

Corresponding Author:

Mr. Hugh D. Flood

Department of Urology

Mid-Western Regional Hospital

Dooradoyle

Co Limerick

Ireland

Email: stiflood555@hotmail.com

Phone: 0035361301111 
Keywords:

Urinary incontinence

Intraoperative complications

Endoscopic excsion

Urethral erosion

Bladder erosion

Holmium laser

Thulium laser

Abstract word count: 280

Manuscript word count (including abstract): 2380

Number of references: 19

Number of tables: 3

Number of figures: 1 


\begin{abstract}

\section{Background}

Minimally invasive surgical procedures have gained widespread acceptance for managing stress urinary incontinence (SUI) in female patients. Mesh or suture erosion is a rare complication of anti-incontinence procedures that have traditionally been managed with open surgical approaches.
\end{abstract}

\title{
Objectives
}

To prospectively follow the largest series of patients that underwent endoscopic laser excision of eroded polypropylene mesh or sutures as complications of previous antiincontinence procedures.

\section{Intervention}

Twelve female patients underwent endoscopic laser excision of suture/mesh erosions in one centre over a 10 year period.

\section{Measurements}

Primary outcome variables were requirement for additional endoscopic or open surgery to remove mesh/ sutures. Secondary outcome variables were persistence of urinary symptoms, postoperative complications, continence status and requirement for additional anti-incontinence procedures.

\section{Results and Limitations}

Mean interval from previous surgery to erosion was 59.33 (7-144) months and the duration of presenting symptoms ranged from 3-84 (mean: 19.25) months. Ten patients underwent endoscopic excision of the mesh/suture with the Holmium:YAG laser and two underwent excision with the Thulium:YAG laser. Mean operative duration was 19.33 (10-25) minutes and the duration of follow-up was 65.5 (6-134) months. Postoperatively, 6 patients remained asymptomatic and 2 required a rectus 
fascial sling for recurrence of SUI. Four patients underwent a second endoscopic excision due to persistence of erosion. One patient ultimately required an open cystotomy to remove the eroded biomaterial. No intraoperative complications were recorded and all patients are currently asymptomatic. A limitation to this study is that a randomised control group was not available for comparative purposes.

\section{Conclusions}

Endoscopic laser excision may be an acceptable first-line approach for managing eroded biomaterials due to its high long-term success rate and minimally invasive nature. 


\subsection{Introduction}

Stress urinary incontinence (SUI) is among the top 10 most prevalent medical conditions among adult females (1). Several minimally-invasive surgical procedures for effectively managing SUI have gained widespread acceptance since the introduction of the tension-free vaginal tape (TVT) in 1996 (2). In fact, the popularity of such techniques continues to grow due to decreased morbidity, reduced inpatient stay and cure rates that now approach 95\% (3). Although TVT insertion is considered safe due to its relative ease, there are several reports that describe specific procedure related complications such as bladder perforation (2.5-11.7\%) and mesh or suture erosion (0.6-5.4\%) (1). Bladder perforations are typically recognised intraoperatively with cystourethroscopy and can often be managed without additional therapy apart from prolonged transurethral catheterisation (4). Erosions are less common and are encountered almost exclusively with synthetic biomaterials. An eroded mesh may go unrecognised for several months due to the wide variety of non-specific presenting symptoms that may lead to delays in diagnostic investigations (5).

Initially, erosion into the urinary bladder required an open cystotomy for effective and definitive management (6). Intuitively, less invasive endoscopic approaches with transurethral electroresection or endoscopic scissors were described subsequent to invasive open techniques $(4,7)$. However, recent studies have used the holmium laser as an alternative tool for excising the eroded material from the lower genitourinary tract. This endoscopic technique was pioneered by our institution in 2005 (5) and has increasing in popularity due to its minimal morbidity and low complication rates. The safety and effectiveness of the holmium laser is reflected by the fact that $95 \%$ of its energy is absorbed after traversing $0.5 \mathrm{~mm}$ underwater. Consequently, its energy is 
contained superficially and therefore conveys excellent underwater cutting properties (5, 8-10). To date, studies describing the use of laser therapy for excising an eroded mesh or suture have been limited to case reports and small case series without sufficient long-term follow-up data (11). In this study we present the largest series of patients that underwent endoscopic laser excision of eroded polypropylene mesh or sutures as complications of previous anti-incontinence procedures. We also discuss the long-term clinical outcomes associated with this minimally invasive technique and compare our results with other published studies. 


\subsection{Materials and Methods}

\subsection{Patient demographics}

Patients with intravesical or urethral exposure to polypropylene mesh and/or sutures after anti-incontinence procedures were followed-up prospectively over a 10 year period at our institution. Their records were retrieved and data extracted. The relevant information gathered included age at presentation and past urological/ gynaecological surgical procedures. The patient's presenting symptoms, their duration and preoperative diagnostic investigations were also recorded. In addition, the time interval between prior urological/ gynaecological procedure and endoscopic laser excision was documented.

\subsection{Technique for endoscopic laser excision}

All patients were in the lithotomy position under general anaesthesia or sedation and given perioperative intravenous gentamicin $(5 \mathrm{mg} / \mathrm{kg}$ body weight). All procedures were performed as a day procedure by one surgeon (H.F). Cystourethroscopy was performed and the laser fibre advanced through the working channel of the endoscope. Initially, all calcified material was fragmented off the polypropylene with the laser (Fig. 1a). The mesh fibres were then melted with the laser deep to the mucosal surface (Fig. 1b). The resected specimen was then extracted endoscopically. In technically challenging cases the edges of the eroded mesh or suture were grasped with a stent grasper (placed alongside the cystoscope) to stabilise the mesh/ suture by applying tension before deploying the laser (Fig. 1c). All patients were catheterised during the immediate postoperative period for 1-3 days and covered with oral 
ofloxacin for 72 hours. The relevant intraoperative data recorded included the location of the exposed/ eroded material, the type of laser fibre deployed, the laser's output settings, the duration of the procedure and any procedure related complications.

\subsection{Postoperative follow-up}

All patients underwent flexible cystourethroscopy at 3 months follow-up. Patients were then followed up on a 6 monthly outpatient basis thereafter with an interview, physical examination and urinalysis. Any patient that presented with recurrence of their symptoms during the follow-up period underwent urodynamics and repeat cystourethroscopy. The primary outcome variables measured were the requirement for additional endoscopic or open surgery to remove mesh/ sutures. Secondary outcome variables were persistence of urinary symptoms, postoperative complications, continence status and the requirement for additional anti-incontinence procedures. 


\subsection{Results}

\subsection{Patient demographics}

Between January 2002 and January 2012 twelve female patients were referred to our institution for endoscopic management of suture/mesh erosions after anti-incontinence procedures. Table 1 demonstrates the relevant patient demographics. The mean age at presentation was 54.83 (47-73) years. Ten patients had previously undergone transvaginal-tape (TVT) for the management of SUI, one patient had a history of Burch colposuspension and one patient previously underwent and anterior colporrhaphy and Stamey vesicopexy. The mean interval from surgery to erosion was 59.33 (7-144) months. Presenting symptoms included macro- and microscopic haematuria, recurrent SUI, recurrent UTIs and suprapubic pain. The duration of presenting symptoms ranged from 3-84 (mean: 19.25) months. All intravesical/ urethral erosions/ exposures were diagnosed with flexible cystourethroscopy.

\subsection{Intraoperative findings}

The relevant intraoperative findings are demonstrated in table 2 . There were 10 intravesical erosions and 2 erosions into the urethra. Eroded TVT mesh was identified in eight patients and polypropylene sutures were identified in the remaining four. Ten patients underwent endoscopic excision of the mesh/suture with the Holmium:YAG laser (VersaPulse ${ }^{\circledR}$ PowerSuite ${ }^{\mathrm{TM}}$ ) and two underwent excision with the Thulium:YAG laser (RevoLix $\left.{ }^{\circledR}\right)$. Laser fibre length varied from $200 \mu \mathrm{m}$ to $550 \mu \mathrm{m}$ and output settings varied from 0.8 Joules at 10 Hertz to 1.2 Joules at 10-15 Hertz. The mean operative time was $19.33(10-25)$ minutes and there were no intraoperative complications. 


\subsection{Postoperative follow-up}

Table 3 demonstrates the relevant post-operative follow-up data. The mean duration of follow-up was 65.5 (6-134) months. Six patients remained asymptomatic and 2 required a rectus fascial sling for persistence of SUI. Four patients underwent a second endoscopic excision due to persistence of the eroded material. Patients with persistent erosion presented with recurrence of their symptoms within 12 (1-12) months of their initial endoscopic procedure. In one patient, a third endoscopic procedure was required due to persistent mesh erosion at the bladder neck. Ultimately, an open cystotomy was performed on this patient due to persistence of the eroded mesh and the calcified tape was successfully extracted. At present, all patients are continent of urine and remain asymptomatic. 


\subsection{Discussion}

Laser therapy has an established role in endoscopic urology; in particular for the treatment of benign prostatic hyperplasia $(\mathrm{BPH})$ and urolithiasis. Although the holmium:YAG laser has been applied to treat mesh and suture erosions after antiincontinence procedures, previous reports have been limited to single case studies and small case series without sufficient long-term follow-up data. Therefore urologists may be reluctant to advocate laser therapy as the 'gold-standard' surgical tool for excising biomaterials that have eroded into the urinary bladder or urethra. In the current study we present the largest case series of patients undergoing endoscopic laser excision with a mean postoperative follow-up of 65.5 months. Our main finding is that endoscopic laser excision of eroded biomaterials appears to be an effective, swift and minimally invasive solution to this problem.

In our case series the distribution of presenting symptoms varied widely. Recurrent urinary tract infections (UTIs) and intermittent macro-/microscopic haematuria were the most prevalent presenting complaints and were found in $42 \%(\mathrm{n}=5 / 12)$ and $58 \%$ $(n=7 / 12)$ of females respectively. These findings are consistent with other studies that describe macro-/microscopic haematuria and recurrent UTIs as predominant symptoms in erosive complications $(9,12-13)$. Other common presenting symptoms are suprapubic discomfort, recurrent SUI, de novo frequency and de novo urgency. These irritative symptoms are likely to have developed from direct contact of a foreign body with host urine leading to encrustation and calcification of the eroded biomaterial. Notably, the mean duration of presenting symptoms prior to diagnosis was prolonged at 19.25 months. This finding suggests that clinicians are often misled with erosive complications with resultant diagnostic delays and higher indices of 
suspicion should be adopted; particularly in the context of prior anti-incontinence surgery and the aforementioned presenting symptoms.

A number of different hypotheses have been postulated on the pathogenesis of mesh or suture erosion. Trocar perforation is usually recognised intraoperatively, however a lack of familiarity with $70^{\circ}$ endoscopes can occasionally lead to unrecognised perforations; particularly if the 11 and 1 o'clock regions of the urinary bladder are not accurately inspected. Furthermore, insufficient distension of bladder tissue at the time of intraoperative inspection may also prohibit direct visualisation of an occult perforation. Another explanation is gradual erosion of the material into the urinary bladder or urethra over time precipitated by submucosal placement of the tape or suture during the initial procedure (4-5). Perhaps, the latter hypothesis is more likely in this study as the mean interval from previous anti-incontinence surgery to erosion was 59.33 months.

Diagnostic cystourethroscopy should be performed on all patients after endoscopic laser excision as the recurrence rate for erosion was 33\% (4/12) within 12 months of the initial excision procedure. Re-epithelialisation over the resected defect is more likely to occur if excision is not performed 2-3 $\mathrm{mm}$ deep to the mucosal surface. In our study, one patient ultimately required an open cystotomy to retrieve the eroded mesh as resection to the deeper urothelium was not feasible due to technical difficulties with endoscopic accessibility. In addition, two patients required an autologous rectus fascial sling for recurrence of SUI; however both patients are currently dry and continent. Our excision success rate of $92 \%(11 / 12)$ compares favourably with other smaller case series where the success rate for complete 
endoscopic excision with laser therapy ranges from $50 \%$ to $100 \%(10,13)$. In general, other approaches at erosive excisions are more invasive and involve an open suprapubic, transvaginal or transabdominal approach (12, 14-16). Advantages of the endoscopic laser approach include decreased inpatient stay, decreased catheter duration, low rates of recurrence and good functional outcomes (10).

Notably, our two most recent patients presenting with TVT erosion underwent excision of the tape with the Thulium:YAG laser (RevoLix $\left.{ }^{\circledR}, \lambda=2,000 \mathrm{~nm}\right)$ and this feature is unique to our study. Thulium confers a number of potential advantages over the Holmium:YAG (VersaPulse ${ }^{\circledR}$ PowerSuite ${ }^{\mathrm{TM}}, \lambda=2,140 \mathrm{~nm}$ ) laser in this clinical setting. Firstly, thulium's wavelength produces up to four-fold less thermal damage to soft tissue when compared to holmium, thereby reducing the risk of intraoperative bladder perforation or irreversible damage to urethral tissue (17). Additionally, the thulium laser offers greater flexibility for use in flexible cystosurethroscopes permitting improved access to erosions that are in challenging anatomical locations. Also, higher irrigation rates allow for improved visibility and can therefore make technically difficult procedures more feasible (18). Finally, the thulium laser fibre releases a continuous, operator dependent, pulse when deployed and is 5-10 times more efficient than the conventional holmium:YAG laser for vaporizing urinary tract calculi at identical pulse energies. Therefore, this option offers a more cost-effective alternative and may reduce the duration of general anaesthesia (19).

A limitation to this study is that a randomised control group was not available for comparative purposes due to the infrequency of erosive complications after antiincontinence procedures (1). However, we believe the relatively large number of 
cases presented and long-term follow-up data at hand demonstrates that endoscopic laser excision appears to be an acceptable first-line, minimally invasive option for managing intravesical/urethral suture and mesh erosions. We also believe that the thulium:YAG laser may offer an attractive alternative to the holmium:YAG laser in this clinical setting in the near future. It has the potential for improved access to awkwardly located biomaterials that have eroded and may reduce the frequency of intraoperative thermal damage to surrounding tissues. However additional, prospective, randomised trials will be required in the near future to comparatively evaluate both laser types.

\subsection{Conclusion}

As the TVT procedure continues to increase in popularity, a concomitant increase in erosive complications is likely to occur. In this study, we prospectively followed twelve patients who underwent endoscopic laser excision of an eroded mesh or suture after anti-incontinence procedures. Our results demonstrate that endoscopic laser excision may be an acceptable first-line approach for managing eroded biomaterials due to its high success rate and minimally invasive nature. Information gathered from this study provides important knowledge on the clinical presentation and management strategies for erosive complications after anti-incontinence surgery. 


\subsection{References}

1. Novara G, Galfano A, Boscolo-Berto R, Secco S, Cavalleri S, Ficarra V, et al. Complication rates of tension-free midurethral slings in the treatment of female stress urinary incontinence: a systematic review and meta-analysis of randomized controlled trials comparing tension-free midurethral tapes to other surgical procedures and different devices. Eur Urol. 2008 Feb;53(2):288-308.

2. Ulmsten U, Henriksson L, Johnson P, Varhos G. An ambulatory surgical procedure under local anesthesia for treatment of female urinary incontinence. Int Urogynecol J Pelvic Floor Dysfunct. 1996;7(2):81-5; discussion 5-6.

3. Latthe PM, Foon R, Toozs-Hobson P. Transobturator and retropubic tape procedures in stress urinary incontinence: a systematic review and meta-analysis of effectiveness and complications. BJOG. 2007 May;114(5):522-31.

4. Huwyler M, Springer J, Kessler TM, Burkhard FC. A safe and simple solution for intravesical tension-free vaginal tape erosion: removal by standard transurethral resection. BJU Int. 2008 Aug 5;102(5):582-5.

5. Giri SK, Drumm J, Flood HD. Endoscopic holmium laser excision of intravesical tension-free vaginal tape and polypropylene suture after anti-incontinence procedures. J Urol. 2005 Oct;174(4 Pt 1):1306-7.

6. Volkmer BG, Nesslauer T, Rinnab L, Schradin T, Hautmann RE, Gottfried HW. Surgical intervention for complications of tension-free vaginal tape procedure. J Urol. 2003 Feb;169(2):570-4.

7. McLennan MT. Transurethral resection of transvaginal tape. Int Urogynecol J Pelvic Floor Dysfunct. 2004 Sep-Oct;15(5):360-2. 
8. Lane BR, Singh D, Meraney A, Streem SB. Novel endourologic applications for holmium laser. Urology. 2005 May;65(5):991-3.

9. Doumouchtsis SK, Lee FY, Bramwell D, Fynes MM. Evaluation of holmium laser for managing mesh/suture complications of continence surgery. BJU Int. 2011 Nov;108(9):1472-8.

10. Sakalis VI, Gkotsi AC, Triantafyllidis A, Giouris A, Charalambous S. Transurethral holmium laser intravesical tape excision following TVT procedure: results from seven patients in a 12-month follow-up. Int Urogynecol J. 2011 Sep 28.

11. Hodroff M, Portis A, Siegel SW. Endoscopic removal of intravesical polypropylene sling with the holmium laser. J Urol. 2004 Oct;172(4 Pt 1):1361-2.

12. Velemir L, Amblard J, Jacquetin B, Fatton B. Urethral erosion after suburethral synthetic slings: risk factors, diagnosis, and functional outcome after surgical management. Int Urogynecol J Pelvic Floor Dysfunct. 2008 Jul;19(7):9991006.

13. Frenkl TL, Rackley RR, Vasavada SP, Goldman HB. Management of iatrogenic foreign bodies of the bladder and urethra following pelvic floor surgery. Neurourol Urodyn. 2008;27(6):491-5.

14. Wohlrab KJ, Erekson EA, Myers DL. Postoperative erosions of the Mersilene suburethral sling mesh for antiincontinence surgery. Int Urogynecol J Pelvic Floor Dysfunct. 2009 Apr;20(4):417-20.

15. Tsivian A, Kessler O, Mogutin B, Rosenthal J, Korczak D, Levin S, et al. Tape related complications of the tension-free vaginal tape procedure. J Urol. 2004 Feb;171(2 Pt 1):762-4. 
16. Sweat SD, Itano NB, Clemens JQ, Bushman W, Gruenenfelder J, McGuire EJ, et al. Polypropylene mesh tape for stress urinary incontinence: complications of urethral erosion and outlet obstruction. J Urol. 2002 Jul;168(1):144-6.

17. Schomacker KT, Domankevitz Y, Flotte TJ, Deutsch TF. Co:MgF2 laser ablation of tissue: effect of wavelength on ablation threshold and thermal damage. Lasers Surg Med. 1991;11(2):141-51.

18. Blackmon RL, Irby PB, Fried NM. Thulium fiber laser lithotripsy using tapered fibers. Lasers Surg Med. 2010 Jan;42(1):45-50.

19. Blackmon RL, Irby PB, Fried NM. Holmium:YAG (lambda = 2,120 nm) versus thulium fiber (lambda $=1,908 \mathrm{~nm}$ ) laser lithotripsy. Lasers Surg Med. 2010 Mar;42(3):232-6. 


\begin{tabular}{|c|c|c|c|c|c|}
\hline $\begin{array}{c}\text { Patient } \\
\text { Number }\end{array}$ & Age & $\begin{array}{c}\text { Previous urological } \\
\text { gynaecological } \\
\text { procedure(s) }\end{array}$ & $\begin{array}{c}\text { Interval from previous } \\
\text { surgery to } \\
\text { exposure/erosion } \\
\text { (months) }\end{array}$ & Presenting symptoms & $\begin{array}{c}\text { Duration of } \\
\text { presenting } \\
\text { symptoms } \\
\text { (months) }\end{array}$ \\
\hline 1 & 49 & TVT & 66 & $\begin{array}{l}\text { Frequency } \\
\text { Recurrent UTIs } \\
\text { Recurrent SUI }\end{array}$ & 3 \\
\hline 2 & 47 & TVT & 84 & $\begin{array}{l}\text { Urgency } \\
\text { Frank haematuria }\end{array}$ & 3 \\
\hline 3 & 56 & TVT & 108 & $\begin{array}{l}\text { Recurrent UTIs } \\
\text { Microscopic haematuria }\end{array}$ & 84 \\
\hline 4 & 48 & TVT & 7 & Intermittent frank haematuria & 2 \\
\hline 5 & 59 & TVT & 144 & Intermittent frank haematuria & 13 \\
\hline 6 & 59 & $\begin{array}{l}\text { TVT } \\
\text { Posterior vaginal prolapse } \\
\text { repair }\end{array}$ & 72 & $\begin{array}{l}\text { Suprapubic pain } \\
\text { Recurrent UTIs }\end{array}$ & 36 \\
\hline 7 & 58 & $\begin{array}{l}\text { Vaginal hysterectomy } \\
\text { Urethroscopic fistula repair } \\
\text { TVT sling }\end{array}$ & 36 & Recurrent SUI & 64 \\
\hline 8 & 73 & TVT & 30 & $\begin{array}{l}\text { Suprapubic pain radiating to } \\
\text { vagina }\end{array}$ & 5 \\
\hline 9 & 57 & TVT & 24 & $\begin{array}{l}\text { Urgency } \\
\text { Post exercise haematuria }\end{array}$ & 5 \\
\hline 10 & 48 & TVT & 9 & $\begin{array}{l}\text { Recurrent UTIs } \\
\text { Intermittent frank haematuria }\end{array}$ & 3 \\
\hline 11 & 57 & Burch colposuspension & 60 & Intermittent frank haematuria & 1 \\
\hline 12 & 47 & $\begin{array}{l}\text { Anterior colporrhaphy and } \\
\text { Stamey vesicopexy }\end{array}$ & 72 & $\begin{array}{l}\text { Recurrent UTIs } \\
\text { Frequency } \\
\text { Urgency }\end{array}$ & 12 \\
\hline
\end{tabular}

Table 1: Demographics of patients presenting with erosions after previous antiincontinence surgical procedures and their presenting symptoms 


\begin{tabular}{|c|c|c|c|c|c|}
\hline $\begin{array}{c}\text { Patient } \\
\text { Number }\end{array}$ & $\begin{array}{c}\text { Eroded } \\
\text { material }\end{array}$ & Erosion/ Exposure site & $\begin{array}{c}\text { Laser type and } \\
\text { fibre length }\end{array}$ & $\begin{array}{c}\text { Laser } \\
\text { Settings }\end{array}$ & $\begin{array}{l}\text { Duration of } \\
\text { procedure } \\
\text { (minutes) }\end{array}$ \\
\hline 1 & TVT tape & $\begin{array}{l}\text { Urethra: } 5 \mathrm{~mm} \text { from bladder neck, 9-11 } \\
\text { o'clock }\end{array}$ & Holmium, $200 \mu \mathrm{m}$ & $0.8 \mathrm{~J}$ at $8 \mathrm{~Hz}$ & 25 \\
\hline 2 & TVT tape & $\begin{array}{l}\text { Bladder: } 2 \text { o'clock, } 2 \mathrm{~cm} \text { inside bladder } \\
\text { neck }\end{array}$ & Holmium, $365 \mu \mathrm{m}$ & $1 \mathrm{~J}$ at $10 \mathrm{~Hz}$ & 10 \\
\hline 3 & TVT tape & $\begin{array}{l}\text { Urethra: } 5 \text { o'clock, just distal to } \\
\text { sphincter }\end{array}$ & Thulium, $550 \mu \mathrm{m}$ & $0.8 \mathrm{~J}$ at $10 \mathrm{~Hz}$ & 15 \\
\hline 4 & TVT tape & $\begin{array}{l}\text { Bladder: left side of dome } \& \text { right side } \\
\text { of dome }\end{array}$ & Thulium, $550 \mu \mathrm{m}$ & $0.8 \mathrm{~J}$ at $10 \mathrm{~Hz}$ & 20 \\
\hline 5 & TVT tape & $\begin{array}{l}\text { Bladder: } 5 \text { o'clock, } 1 \mathrm{~cm} \text { from bladder } \\
\text { neck }\end{array}$ & Holmium, $500 \mu \mathrm{m}$ & $1 \mathrm{~J}$ at $5-10 \mathrm{~Hz}$ & 18 \\
\hline 6 & $\begin{array}{l}\text { Polypropylene } \\
\text { suture }\end{array}$ & $\begin{array}{l}\text { Bladder: Looping through, } 1 \text { o'clock, } \\
\text { close to bladder neck }\end{array}$ & Holmium, $365 \mu \mathrm{m}$ & $\begin{array}{l}1.2 \mathrm{~J} \text { at } 10- \\
15 \mathrm{~Hz}\end{array}$ & 24 \\
\hline 7 & $\begin{array}{l}\text { Polypropylene } \\
\text { suture }\end{array}$ & Bladder: posterior wall near trigone & Holmium, $365 \mu \mathrm{m}$ & $1 \mathrm{~J}$ at $10 \mathrm{~Hz}$ & 20 \\
\hline 8 & TVT tape & $\begin{array}{l}\text { Bladder: In and out through right lateral } \\
\text { wall ( } 3 \mathrm{~cm} \text { strip) }\end{array}$ & Holmium, $550 \mu \mathrm{m}$ & $1.2 \mathrm{~J}$ at $10 \mathrm{~Hz}$ & 20 \\
\hline 9 & TVT tape & $\begin{array}{l}\text { Bladder: } 2.5 \mathrm{~cm} \text { strip, heavily calcified, } \\
\text { posterior wall }\end{array}$ & Holmium, $365 \mu \mathrm{m}$ & $1 \mathrm{~J}$ at $10 \mathrm{~Hz}$ & 20 \\
\hline 10 & TVT tape & Bladder: left anterolateral bladder wall & Holmium, $365 \mu \mathrm{m}$ & $1 \mathrm{~J}$ at $10 \mathrm{~Hz}$ & 20 \\
\hline 11 & $\begin{array}{l}\text { Polypropylene } \\
\text { suture }\end{array}$ & $\begin{array}{l}\text { Bladder: close to bladder neck on left } \\
\text { ant. Wall }\end{array}$ & Holmium, $365 \mu \mathrm{m}$ & $1 \mathrm{~J}$ at $10 \mathrm{~Hz}$ & 20 \\
\hline 12 & $\begin{array}{l}\text { Polypropylene } \\
\text { suture }\end{array}$ & $\begin{array}{l}\text { Bladder: right ant. Wall close to bladder } \\
\text { neck }\end{array}$ & Holmium, $365 \mu \mathrm{m}$ & $1 \mathrm{~J}$ at $10 \mathrm{~Hz}$ & 20 \\
\hline
\end{tabular}

Table 2: Intraoperative findings and laser output settings used during the endoscopic excision procedure 


\begin{tabular}{|c|c|c|c|c|}
\hline $\begin{array}{l}\text { Patient } \\
\text { Number }\end{array}$ & $\begin{array}{c}\text { Requirement for 2nd laser } \\
\text { excision }\end{array}$ & $\begin{array}{l}\text { Requirement for } \\
3^{\text {rd }} \text { laser excision }\end{array}$ & $\begin{array}{l}\text { Duration of follow- } \\
\text { up since definitive } \\
\text { laser excision }\end{array}$ & Findings at follow-up \\
\hline 1 & No & No & 72 & $\begin{array}{l}\text { Required rectus fascial } \\
\text { sling for recurrent SUI } \\
\text { Currently dry }\end{array}$ \\
\hline 2 & No & No & 72 & Dry \\
\hline 3 & No & No & 24 & Dry \\
\hline 4 & No & No & 6 & Dry \\
\hline 5 & $\begin{array}{l}\text { Yes } \\
\text { (Remnant TVT excised } 12 \text { months } \\
\text { after initial excision: Holmium } \\
365 \mu \mathrm{m} ; 0.8 \mathrm{~J} \text { at } 10 \mathrm{~Hz} \text { ) }\end{array}$ & No & 134 & Dry \\
\hline 6 & $\begin{array}{l}\text { Yes } \\
\text { (Remnant suture deep in bladder } \\
\text { wall excised } 5 \text { weeks after initial } \\
\text { excision: Holmium } 365 \mu \mathrm{m} ; 0.8 \mathrm{~J} \text { at } \\
10 \mathrm{~Hz} \text { ) }\end{array}$ & No & 70 & Dry \\
\hline 7 & No & No & 48 & Dry \\
\hline 8 & $\begin{array}{l}\text { Yes } \\
\text { (Remnant TVT excised } 6 \text { months } \\
\text { after initial excision: Holmium: } 1.4 \mathrm{~J} \\
\text { at } 15 \mathrm{H} \text { ) }\end{array}$ & No & 60 & Dry \\
\hline 9 & $\begin{array}{l}\text { Yes } \\
\text { Remnant TVT excised from bladder } \\
\text { neck } 12 \text { months after initial } \\
\text { excision: Holmium } 365 \mu \mathrm{m}: 1 \mathrm{~J} \text { at } 10 \\
\mathrm{~Hz} \text { ) }\end{array}$ & $\begin{array}{l}\text { Yes } \\
{\text { (3years after } 2^{\text {nd }}} \\
\text { excision: Thulium } \\
550 \mu \mathrm{m}: 1 \mathrm{~J} \text { at } 10 \\
\mathrm{~Hz})\end{array}$ & - & $\begin{array}{l}1 \text { year after, required } \\
\text { open cystotomy and } \\
\text { removal of calcified } \\
\text { tape. } \\
\text { Currently Dry }\end{array}$ \\
\hline 10 & No & No & 98 & Dry \\
\hline 11 & No & No & 96 & Dry \\
\hline 12 & No & No & 100 & $\begin{array}{l}\text { Required rectus fascial } \\
\text { sling for recurrent SUI. } \\
\text { Currently dry }\end{array}$ \\
\hline
\end{tabular}

Table 3: Long-term follow-up data for patients undergoing endoscopic laser excision

of eroded mesh or sutures after previous anti-incontinence surgery 

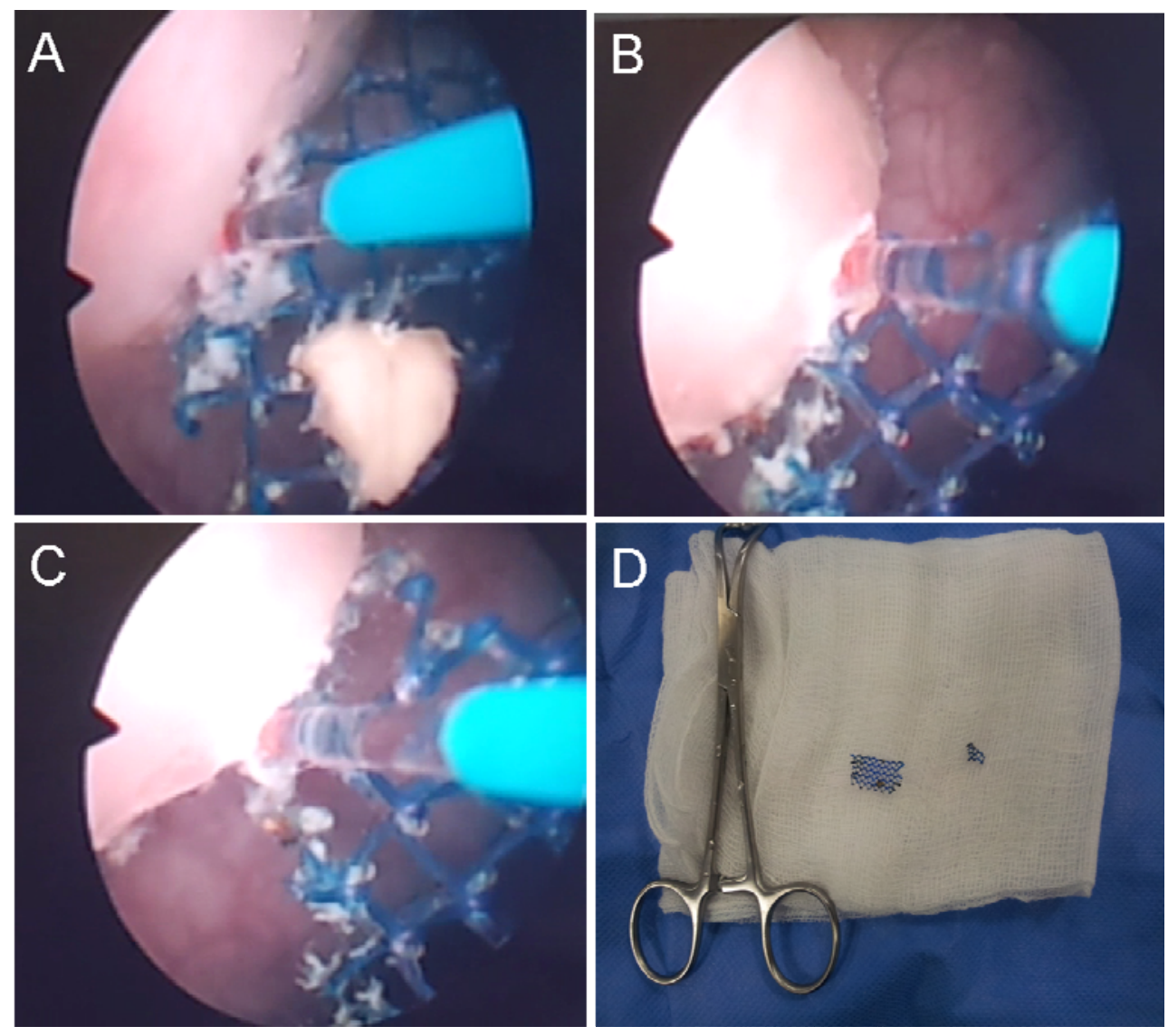

Figure 1: Intraoperative images demonstrating surgical technique for endoscopic laser excision of eroded TVT. The mesh was initially cauterised with the laser fibre (A) and a resection deep to bladder mucosa was performed to remove any residual material (B). For technically challenging cases the edges of the eroded mesh or suture were grasped with a stent grasper to stabilise the mesh by applying tension before deploying the laser (C). Resected specimens were then extracted endoscopically (D). 